\title{
A New Evaluation of the USGS Streamgaging Network
}

\section{A Report to Congress}

November 30, 1998 


\section{A New Evaluation of the USGS Streamgaging Network}

A Report to Congress

November 30, 1998 


\section{U.S. DEPARTMENT OF THE INTERIOR}

Bruce Babbitt, Secretary

\section{U.S. GEOLOGICAL SURVEY}

Charles G. Groat, Director

For additional information or copies of this report contact:

Chief, Office of Surface Water

U.S. Geological Survey, Water Resources Division

12201 Sunrise Valley Drive

Mail Stop 415

Reston VA 20192 


\section{CONTENTS}

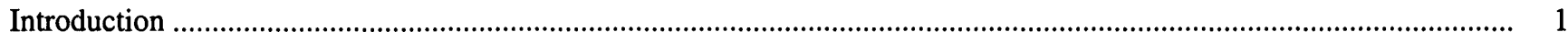

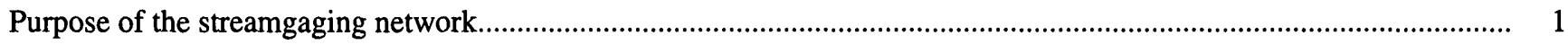

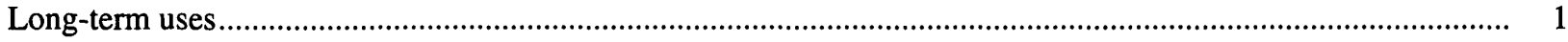

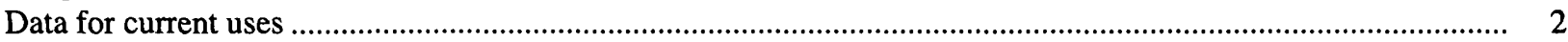

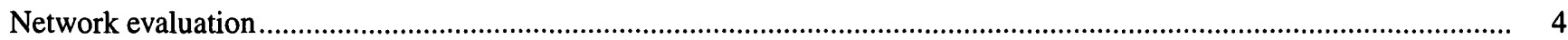

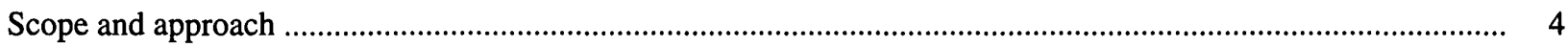

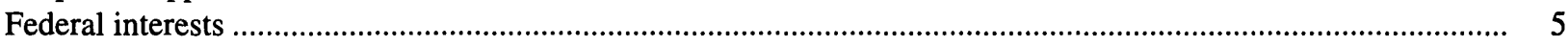

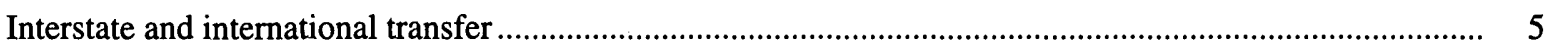

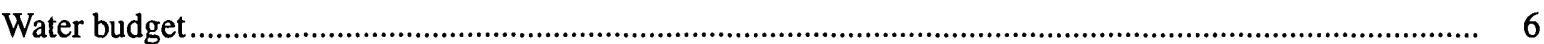

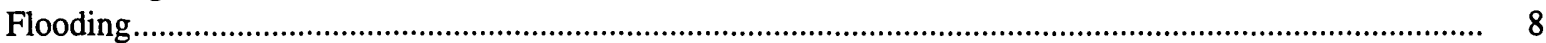

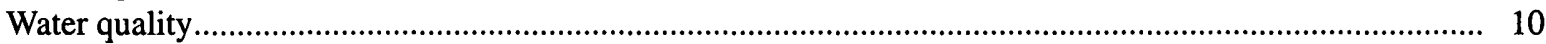

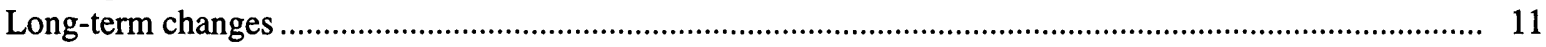

Other measurements of the loss of information needed to evaluate environmental change .................................. 13

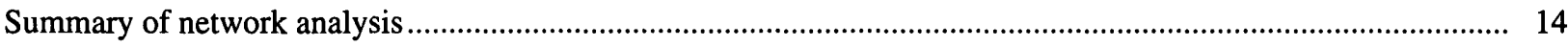

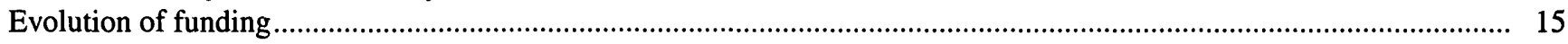

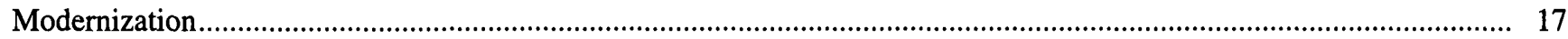

Future direction - National Streamflow Information Program......................................................................................... 18

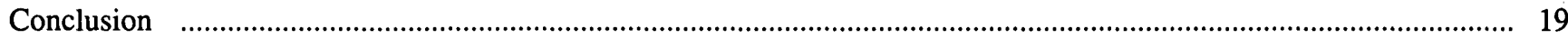

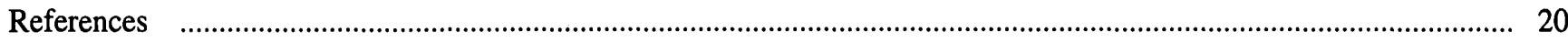

\section{FIGURES}

1. Graph showing increase in the use of satellite telemetry at USGS streamgaging stations ............................. 3

2. Real-time hydrograph, or plot of streamflow vs. time, served on the World Wide Web................................ 3

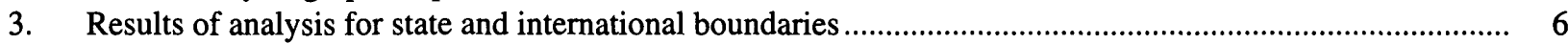

4. Results of analysis for water budgets................................................................................................ 7

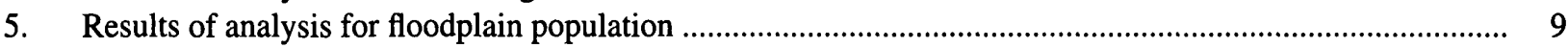

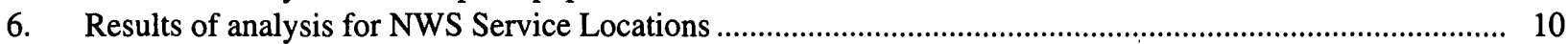

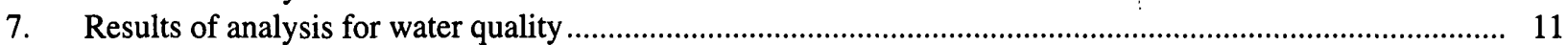

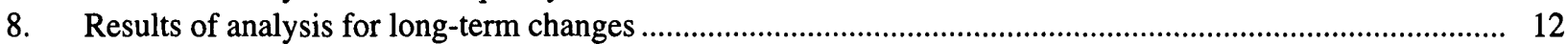

9. Graph showing number of stations with 30 or more years or record discontinued each year, 1921-1995...... 13

10. Graph showing number of HCDN stations ...........................................................................................

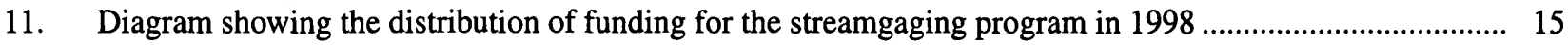

12. Graph showing annual distribution of funding for the streamgaging program, 1974-1998 ........................ 16 



\section{A NEW EVALUATION OF THE USGS STREAMGAGING NETWORK}

\section{INTRODUCTION}

Since 1889, the U.S. Geological Survey (USGS) has operated a streamgaging network to collect information about the Nation's water resources. It is a multipurpose network funded by the USGS and many other Federal, State and local agencies. Individual streamgaging stations are supported for specific purposes such as water allocation, reservoir operations, or regulating permit requirements, but the data are used by others for many purposes. Collectively, the USGS streamgaging network produces valuable data that are used for current forecasting and operational decisions as well as long-term resource planning, infrastructure design, and flood hazard mitigation. The guiding principles of the network are:

- Streamgaging stations are funded by the USGS and many agencies to achieve the Federal mission goals of the USGS and the individual goals of the funding agencies.

- Data are freely available to the public and all partners.

- USGS operates the network on behalf of all partners, which achieves economies because it eliminates the need for multiple infrastructures for testing equipment, providing training to staff, developing and maintaining the communications and database systems, and conducting quality assurance.

- USGS brings the capability of its national staff to bear on challenging problems such as responding to catastrophic floods or finding solutions to unique streamgaging conditions.

This report has been prepared in response to a request from the U.S. House of Representatives Subcommittee on Interior Appropriations in its report to accompany H.R. 4193.

\section{PURPOSES OF THE STREAMGAGING NETWORK}

\section{Long-Term Uses}

Streamgaging became an organized part of the USGS in 1889 when John Wesley Powell, the second Director of the USGS, requested that streamflow be monitored in eight river basins in the arid West. The purpose of the initial stations was very specific: to appraise the water resources of these rivers to determine the potential for irrigation development, which was vital to the economic development and settlement of the region. Streamgaging expanded rapidly into a nationwide network in recognition that streamflow information was vital to the development not only of agriculture, but of industry, urban water supplies, and navigation. 
USGS streamgaging information serves many agencies:

\section{"The USGS in its'} governmental role, integrates multiple funding sources to operate a data network that produces much more than if the network were funded and operated by many separate entities....The unbiased and consistent manner in which the data are collected is extremely important to activities such as diversion accounting between states and regions, settling multistate water disputes, analysis of long term trends in stream flow, etc." [Russell L. Fuhrman, Major General, U.S. Army, Director of Civil Works, written comm., 1996]

"The U.S. Geological Survey stream gaging network is vital to the National Weather Service's river forecast and warning program and the goal to reduce flood damages and loss of life. Without the data from this network, this nation would experience increased losses from floods of both life and property" [Elbert W. Friday, Jr., Assistant Administrator for Weather Services, National Weather Service, written commun., January 19,1995$]$
In parallel with the growing needs for streamflow information for water-supply planning and design was a need for information about floods. Devastating floods such as the Flood of 1913 in the Miami River Valley of Ohio, the Mississippi River Flood of 1927, and a series of massive floods in the eastern United States during the 1930's increased the awareness of the need for flood hazard information and spurred the Federal Government into action with programs to prevent or mitigate the impacts of floods, including the building of flood-control dams, levees, and flood walls. The management of economic activities within floodprone areas became an important part of flood-damage mitigation, and the National Flood Insurance Act of 1968 created the National Flood Insurance Program.

Recently, especially since the passage of the Endangered Species Act in 1973, streamflow records have been used to evaluate the riverine and riparian habitat and conditions needed to maintain or enhance populations of birds, fish, and other organisms that depend on those rivers. These analyses of flow conditions are used to set instream-flow requirements. Scientists and citizens also have become more conscious of the potential for human activity to change the regional and even the global environment. A baseline national network of streamgaging stations provides an initial measure for detecting changes in the environment that will affect future generations (Cleaves, 1998).

\section{Data for Current Uses}

While the streamgaging network serves future and long-term needs, it also serves day-to-day needs of decisionmakers who want data that are current to within a few minutes or hours. The USGS has responded to this need by expanding the use of satellite telemetry to relay data from streamgaging stations to USGS offices and the primary users of streamflow data. The number of stations equipped with satellite telemetry increased from 14 percent in 1983 to 64 percent in 1997 (fig.1).

One of the most important current users of real-time streamflow data is the National Weather Service (NWS), of the National Oceanic and Atmospheric Administration (NOAA). The NWS has responsibility to make the streamflow forecasts for the Nation's rivers; they use weather conditions and streamflow data to forecast water-level and streamflow for more than 4,000 locations along the Nation's rivers, lakes, and reservoirs.

Other agencies needing data for current purposes are those with responsibility for operating water resources systems such as dams, locks, diversions, and conjunctive ground-water and surface-water supply systems. These agencies include the U.S. Army Corps of Engineers, Bureau of Reclamation, Tennessee Valley Authority, and a wide range of local, State, regional, and interstate water authorities, as well as private firms that own and operate water resources systems. Various organizations and individuals also are using real-time streamflow data for decisions about recreational activities. 


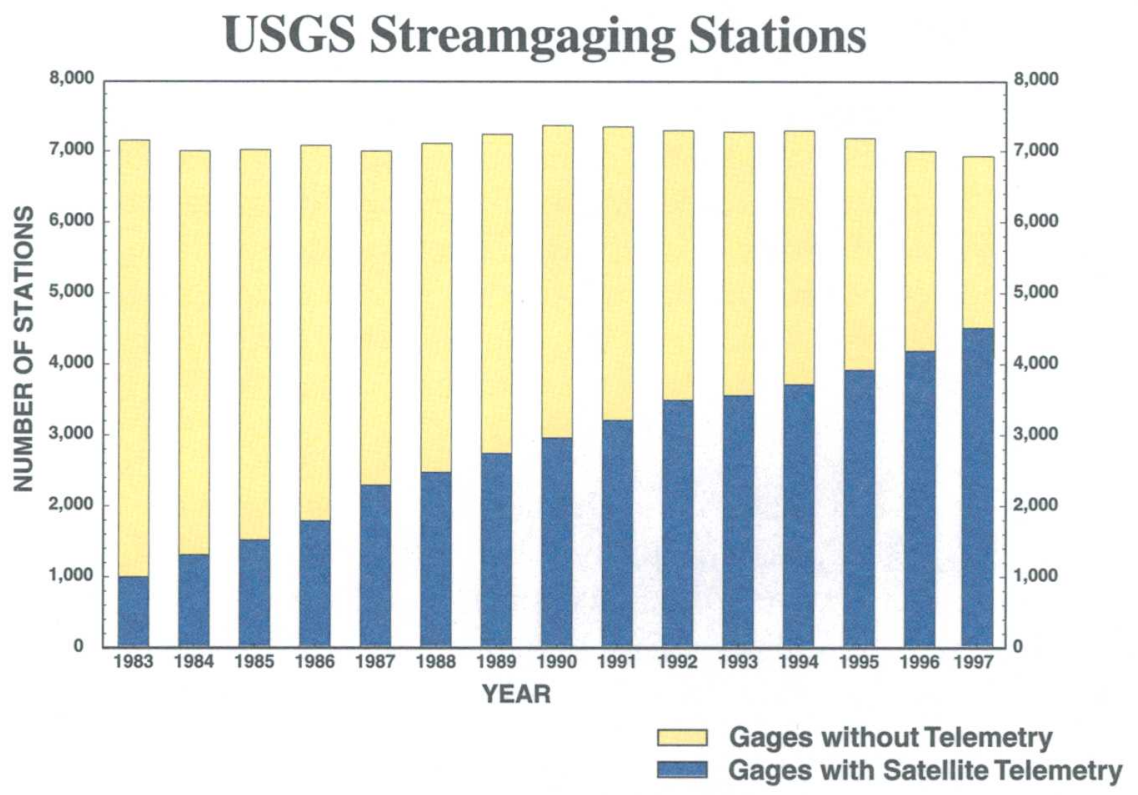

Figure 1.-Graph showing the increase in the use of satellite telemetry at the USGS streamgaging stations.

A recent development in the use of streamflow data is the advent of the internet as a means of disseminating current streamflow data to a wide range of interested users (fig. 2). Presently, there are about 4,000 streamgaging stations for which near real-time data can be rapidly and freely obtained from USGS web-servers by anyone with internet access.

\section{ZUSGS}

02108000 NORTHEAST CAPE FEAR RIVER NEAR CHINQUAPIN, NC

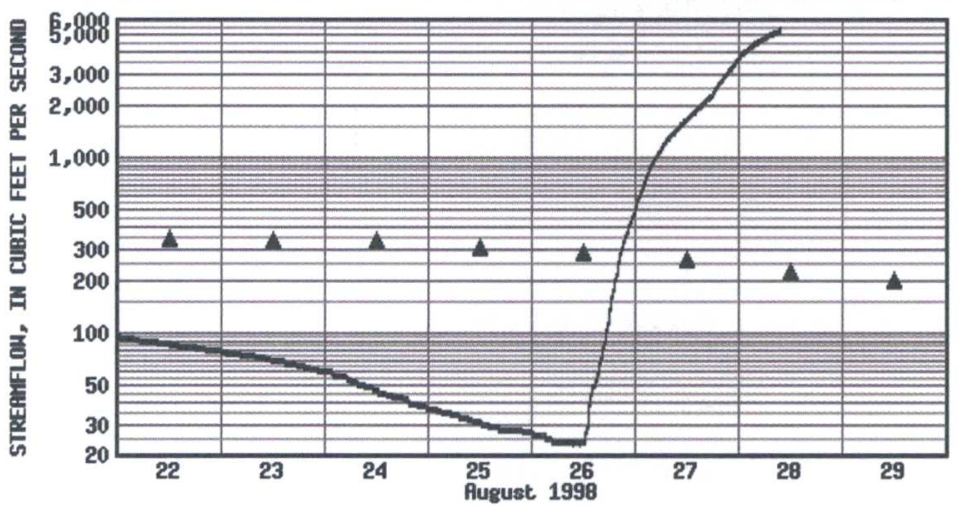

This station is operated in cooperation with the U.S. firny Corps of Engineers.

$$
\begin{aligned}
& \text { Fri Aug } 28 \text { 11:00 } 1998 \\
& \text { STREAMFLOH } \\
& \text { MEDIRN DATLY STREAMFLON, } \\
& \text { based on } 57 \text { years of record }
\end{aligned}
$$

Provia1onal Data Subject To Reviaion

Figure 2-Real-time hydrograph, or plot of streamflow vs. time, served on the World Wide Web shortly after the passage of Hurricane Bonnie in August 1998. Each month, USGS provides more than 250,000 plots like this via the internet to users in government and the private sector. 


\section{NETWORK EVALUATION}

\section{The Geospatial Data Infrastructure}

Over the past two decades, the USGS has continued to build the Nation's archives of digital spatial data. Some of the data sets used for this network analysis include:

- Traces of 60,000 stream segments which constitute a total of about 1 million kilometers of rivers.

- Boundaries of 329 river basins that cover the conterminous United States. These are subdivided into 2100 watersheds.

- Locations of 15 million people in areas at risk from riverine flooding.

- Locations of 18,000 streamgaging stations that have ever been operated by the USGS within the conterminous United States, of which 6,600 were in operation in 1996 (the current endpoint of this analysis).
Any program of long standing, such as the streamgaging network, should be reexamined periodically, if not continuously. A 1970 nationwide evaluation (Benson and Carter, 1973), for example, used statistical methods to test our ability to transfer information from gaged to ungaged sites. As a result, and in recognition that the funds for streamgaging were limited, some longer record stations (greater than 25-30 years) were discontinued in order to redirect those funds to stations that filled voids in the network.

Another evaluation spanned the period 1983-88 and evaluated the utility of using less-costly alternative methods, such as hydrologic or statistical models, to provide the needed streamflow information, and analyzed the relationship between operating budgets and accuracy of the records. These earlier studies have formed the basis of a number of recent efforts in individual USGS Offices to better define a minimum streamgaging network for their States, including Iowa (Fischer, 1996), Maryland (Preston, 1997), Wisconsin (team for evaluating the Wisconsin water-monitoring network, 1998).

However, changes in technology, particularly the availability of geographic information systems (GIS) affords opportunities to examine networks in a different manner. Starting in March 1998 the USGS began a new approach to network evaluation, using the geospatial infrastructure of the national network of rivers and their watersheds. The streamgaging network analysis tool simulates the expert knowledge of hydrologists and applies it to a GIS data base to determine how well the network meets specified goals. What follows is a discussion of how well the streamgaging network meets important Federal goals. Although still a work in progress-many more enhancements are planned - the network analysis tool is sufficiently developed to provide a preliminary assessment of the network,

\section{Scope and Approach}

The evaluation starts with the definition of some key Federal goals for the network and establishes a set of quantitative metrics that define the extent to which the goal is being achieved. These metrics are applied to the network to determine past and present levels of attainment of the goals. In the future, the metrics will be used to assess the value of particular incremental changes in the network. At present, the evaluation has only been implemented for the 48 conterminous United States. The geospatial infrastructure does not currently exist for Alaska, Hawaii and Puerto Rico, however, work is currently underway to resolve this deficiency. 
The technical details of how the network analysis tool operates are beyond the scope of this report.' Simply stated, the tool uses GIS data to identify locations where streamflow information is needed to meet goals. Then, for each of these locations, it looks at the existing network of streamgaging stations and applies hydrologic expert rules to see if one or more stations provide the needed information. (An analysis of this type is, by its nature, only provisional. On-site conditions should always be checked before making a decision concerning a particular gage.) It tallies the met and unmet needs to give an overall measure of success in meeting goals.

\section{Federal Interests}

For this analysis we will focus on five key categories of Federal purposes of the streamgaging network, recognizing that others exist and will be considered later. These purposes are:

-Interstate and international transfers

-Water budgets

-Flooding

-Water-quality

-Long-term changes.

Other Federal functions not addressed here include: supporting Wild and Scenic Rivers; supporting interstate compacts, court decrees, and international treaties; guiding the operation of large Federal reservoirs; managing critical habitat for threatened and endangered species; and defining hydrologic characteristics for designing federally-funded roads, bridges, and water-related infrastructure. Each of the next five sections will describe a particular goal, define the metric to be used, evaluate past and present attainment, make a few observations that interpret the results for that goal, and define the potential use of the results.

\section{Interstate and International Transfers}

The interstate and international transfers goal measures the ability of the network to provide accepted, neutral data for the States to use in the allocation of interstate waters. It requires computing amounts of water transferred across State lines or international borders. The metric was defined in the following manner: Every river reach that crosses a State line or international border and has a drainage area of at least 500 square miles at the crossing point was identified. There are 331 such reaches. The metric is the number of such crossing points that are considered "gaged."

As of 1996, 186 of these 331 crossing points were adequately gaged, for a 56-percent attainment of the goal (fig. 3). Overall, there has been relatively little change for three decades. Attainment of a full 100 percent coverage may not be an appropriate target level for this goal; some of the crossing points are on streams where there is little interstate conflict over the streamflow. Identification of the points not adequately gaged, however, will be useful information in the design discussions that are frequently held between the USGS and the States. 

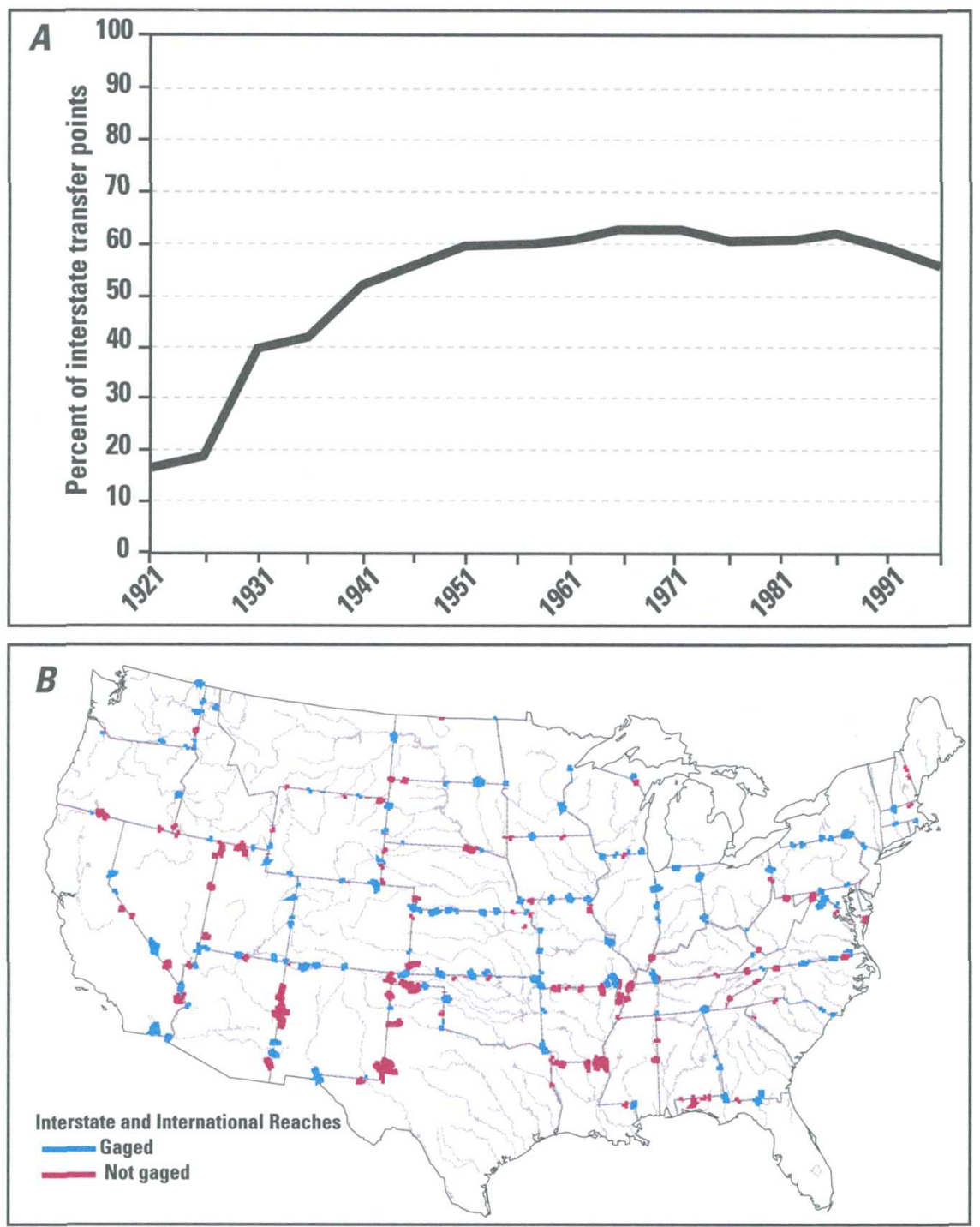

Figure 3.- Results of analysis for State and international boundaries. A. Graph showing percentage of state or international crossing points adequately gaged, 1921-1996. B. Map showing, in cyan, State or international crossing points that were adequately gaged in 1996 . Points not adequately gaged are shown in magenta.

\section{Water Budgets}

The goal is to be able to account for the contribution of water from each major river basin to the next downstream basin or the ocean, estuary or the Great Lakes. Long-term, nationallyconsistent data on the outflows of the major river basins plays a fundamental role in national water policies and planning. The metric is the number of basins that are adequately gaged out of the 329 basins that cover the conterminous United States. 
Currently, 252 of the 329 basins (or 77 percent) are adequately gaged for water budget accounting purposes (fig. 4). The gaps are almost exclusively in smaller coastal basins and in arid regions where there may be no basin outflow at all. In these basins, it is quite difficult to attain adequate coverage because there is no single river that is the outflow point, rather, there are a multitude of smaller streams that drain the basin. Thus, fully 100 percent attainment of this metric is not necessarily a realistic goal, but examination of the areas where it is not achieved is warranted. Vigilance that current levels of attainment are not lost is vital for preserving our ability to define the availability of streamflow and to implement effective water policies.
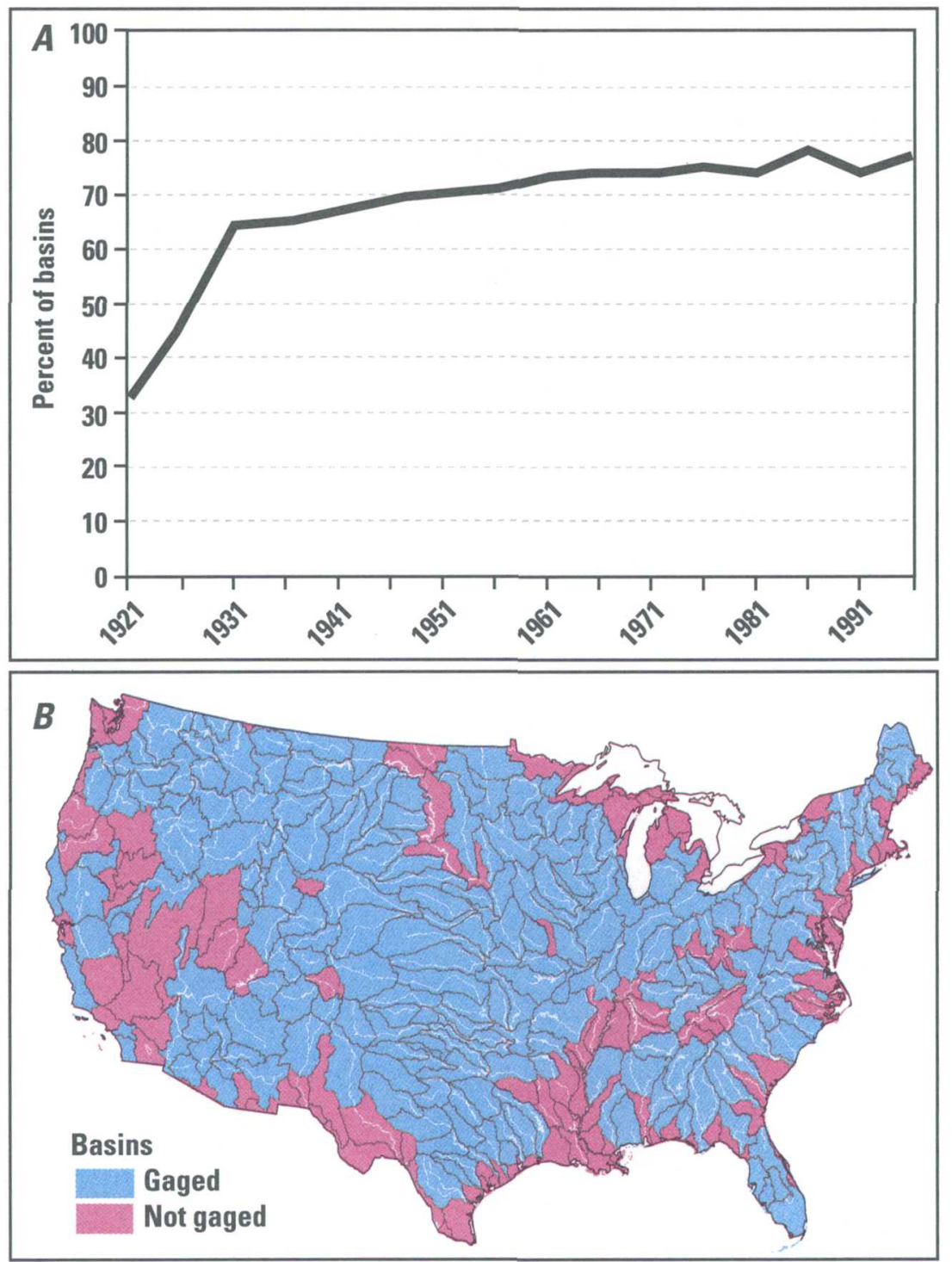

Figure 4 .-Results of analysis for water budgets. A. Graph showing percentage of basins that were adequately gaged, 1921-1996. B. Map showing, in cyan, basins that were adequately gaged in 1996. Basins not adequately gaged are shown in magenta. 


\section{Some feedback from users...}

"Your site has been the best source of river information we have ever been able to obtain to make rescue and evacuation decisions. ... Your work and site is much appreciated and invaluable to us!!! Thanks from the citizens in Hays County."-Emergency Management Official, Texas

"This is not a request. It's a compliment. Congratulations on putting together an excellent and useful source of information on the web. I've used it a lot in the last few weeks. ... I have found that by checking the flows ... I can anticipate increases here and make necessary repairs to dikes and levees. My thanks to you."-Farmer, Texas

"It is $4 \mathrm{AM}$ in the morning. I am right in the middle of the flood on the Snake River. ... The water is now 3 inches to the top of my foundation. I just wanted to let you know that the information I can get off this web page has been invaluable. Thank you so much. No other source of information I can get has been as current or accurate as you wonderful people."-Homeowner, Idaho

"FYI: Your hydrograph and station descriptions for the Neuse River Basin.. have been extremely helpful in our Emergency Management planning during the recent and continued flooding in Craven County. We now are able to predict when evacuations of low lying areas are needed and have on hand historical information to support our requests. Thank you, once again for your services." - Emergency Management Official, North Carolina

\section{Flooding}

The goal is to provide streamflow information for populations at risk from flooding. Long-term records are needed to estimate the flood risk for design of bridges and other structures and to develop accurate flood insurance rate and flood zoning maps. Real-time information is also needed to provide current streamflow conditions to guide emergency decisions and to provide the NWS with streamflow information critical to producing accurate and timely flood forecasts. Two metrics are used for this goal. The first is related directly to populations at risk from flooding. The second relates to support of the NWS forecast function.

There are 18,000 communities that participate in the National Flood Insurance Program (NFIP), and the population at risk within these communities is about 15 million. The metric is the population living on the floodplain in these NFIP-participating communities, near reaches that are adequately gaged. Coverage of the population (fig. 5) is currently at about 42 percent and has declined from 51 percent in 1980.

These results are much more problematic than those for the first two metrics. Recent history of flood losses in the Nation indicate that flood damages are not decreasing and that re-examination of flood risks may be needed (Western Governor's Association, 1997) given new knowledge of long-term climate variability, additional data collected in recent years, and the impacts of land-use changes on flood characteristics. In addition, streamgaging stations now have increased utility to communities at risk of flooding because of the real-time capability. Local governments, citizens, and businesses can monitor changing conditions at nearby and upstream gages and can rely on NWS forecasts and warnings based on the same real-time reports. This type of analysis can provide a basis for discussion with communities that may not be adequately covered by streamgaging stations at the present time. 

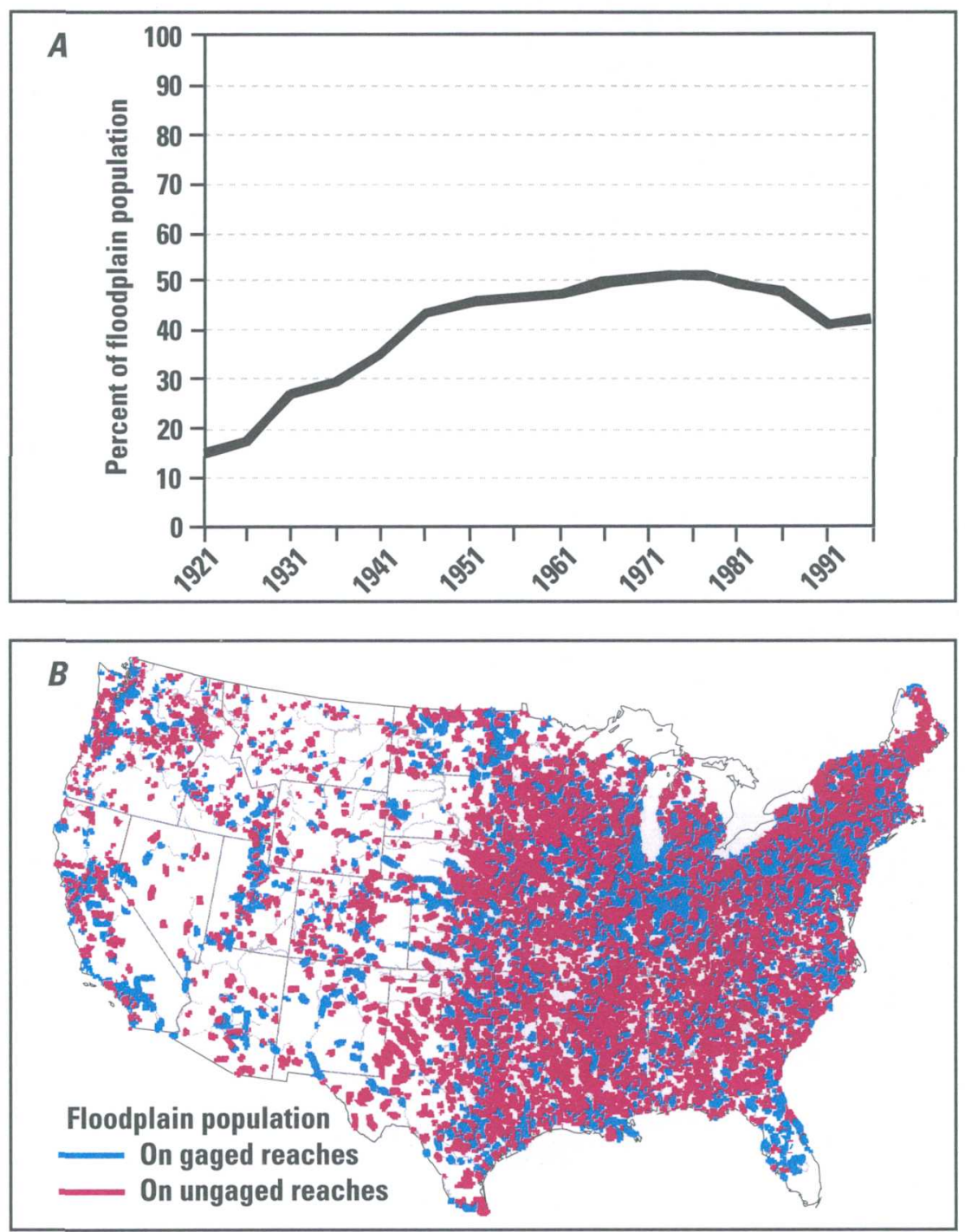

Figure 5.-Results of analysis for floodplain population. A. Graph showing percentage of the (1996) floodplain population on reaches that were adequately gaged, 1921-1996.

$\boldsymbol{B}$. Map showing, in cyan, reaches with floodplain populations that were adequately gaged in 1996. Reaches not adequately gaged are shown in magenta.

Streamflow records are used by the NWS to calibrate river forecasting models. NWS service locations are specific points on rivers for which the NWS delivers forecasts. The goal is to provide real-time water level and streamflow data at the 2,929 NWS service locations on rivers in the conterminous United States. (There are another 466 service locations located on reservoirs, where only stage is required.) Currently, the USGS provides streamflow data for 2,124 of these 2,929 locations or 73 percent of the total (fig. 6).

NWS figures show flood losses for the 50-year period, 1947-96, average $\$ 3.5$ billion per year (constant 1997 dollars); average flood losses for the 5-year period, 1992-96, was $\$ 6.5$ billion per year (National Weather Service, 1998). The gages are becoming increasingly useful in preventing losses (due to real-time capability), and yet the population served and forecast points served have been decreasing. The analysis provides the means to determine key locations where gages need to be placed or reactivated if money became available for meeting this goal. It also provides a basis for examining how stations could be deployed to better meet this goal while also enhancing (or at least not harming) the other Federal goals. 

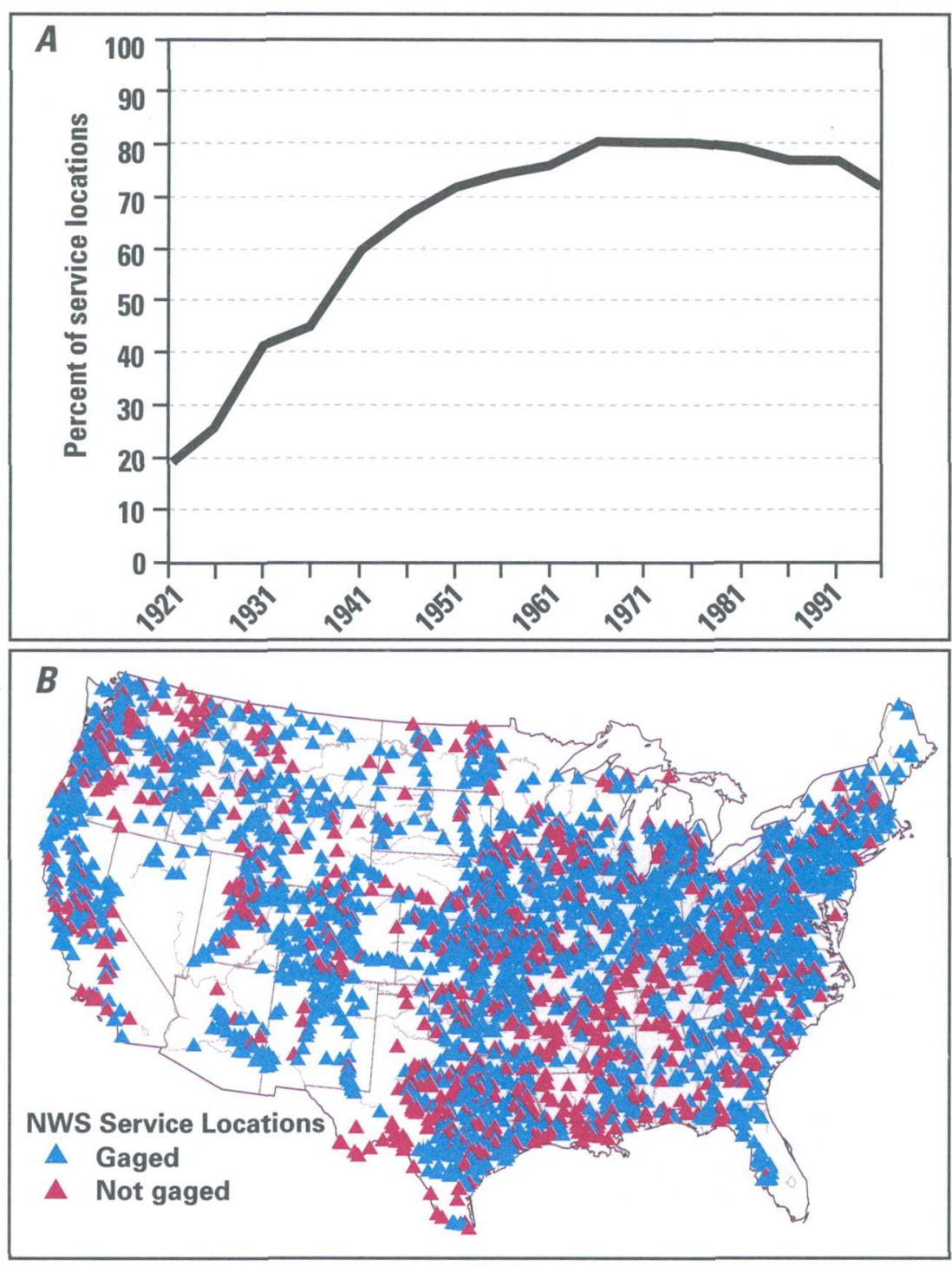

Figure 6.-Results of analysis for NWS Service Locations. A. Graph showing percentage of (1996) NWS Service Locations that were adequately supported by gages, 1921-1996. B. Map showing, in cyan, NWS Service Locations that were adequately gaged in 1996. NWS Service Locations not adequately supported by gages are shown in magenta.

\section{Water Quality}

The water-quality goal is to provide streamflow information to guide the efforts to improve water quality in those watersheds that are known to have degraded water quality. The Index of Watershed Indicators (IWI) published by the U.S. Environmental Protection Agency (EPA) in 1998, defined the watersheds determined by the States to have less than 50 percent of their assessed rivers that meet all designated uses (as established by the relevant State or tribal waterquality standards). The set of degraded watersheds is 677 out of a total of 2,079 possible watersheds in the conterminous United States.

The metric used is the number of these 677 watersheds which are adequately gaged. The metric relates only to the availability of the needed streamflow information and not to the water chemistry or biological data needs. Currently, the level of this metric is that 573 ( 85 percent) 
watersheds are adequately gaged. The percentage has continued to rise over time (fig. 7). The USGS will work with State agencies towards a more detailed, reach-by-reach definition suitable for evaluating specific locations known to be degraded and for which Total Maximum Daily Loads (TMDL) are going to be evaluated under the provisions of the Clean Water Act.
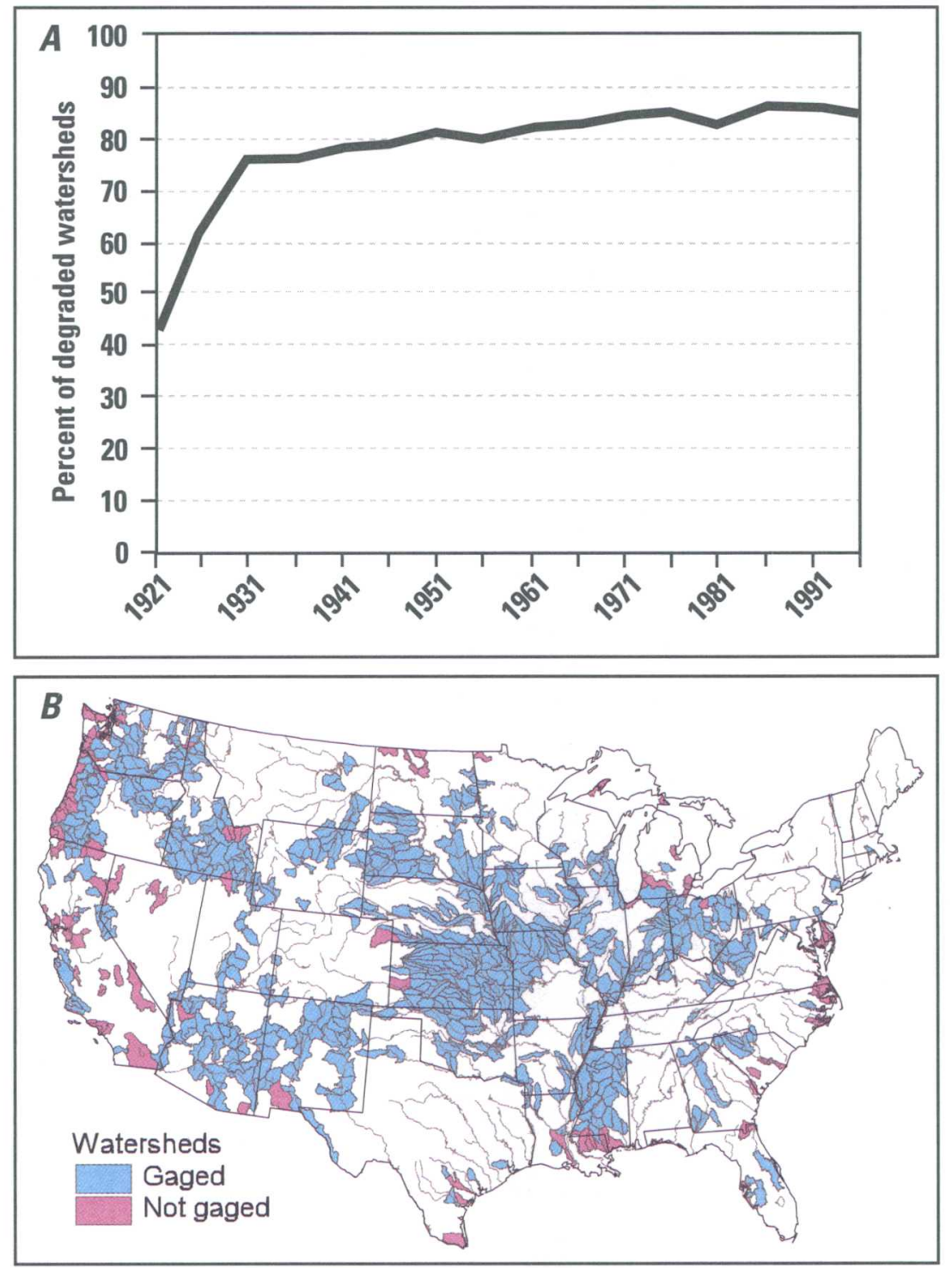

Figure 7.-Results of analysis for water quality. A. Graph showing percentage of (1996) degraded watersheds that were adequately gaged, 1921-1996. B. Map showing, in cyan, degraded watersheds that were adequately gaged in 1996. Degraded watersheds not adequately gaged are shown in magenta.

\section{Long-Term Changes}

The goal that is defined here is to monitor and characterize trends in streamflow in representative streams within each of the Nation's ecoregions. The ecoregions are used, rather than river basins, because they define areas of somewhat homogeneous landscape, elevation, climate and land cover, whereas river basins typically cut across many different natural regions. The term "representative streams" refers to streams whose watershed lies entirely within the ecoregion (as opposed to streams that may simply flow through the ecoregion). These 
representative streams are required to be free of significant regulation or diversion which can distort the results of any analysis of trends in streamflow. The metric is intended to focus on changes in streamflow that would result from changes in climate, changes in land-use practices, or changes in ground-water withdrawals. The metric is the number of ecoregions with a streamgaging station in at least 50 percent of the river basins in the ecoregion.

The results of this analysis show that the metric has declined from 86 percent at its peak in 1976 to a level of 76 percent in 1996 (fig. 8). Given the national concern over long-term environmental change, as driven by potential global climate change and regional land use change, this trend in the streamgaging network is a matter of significant concern.
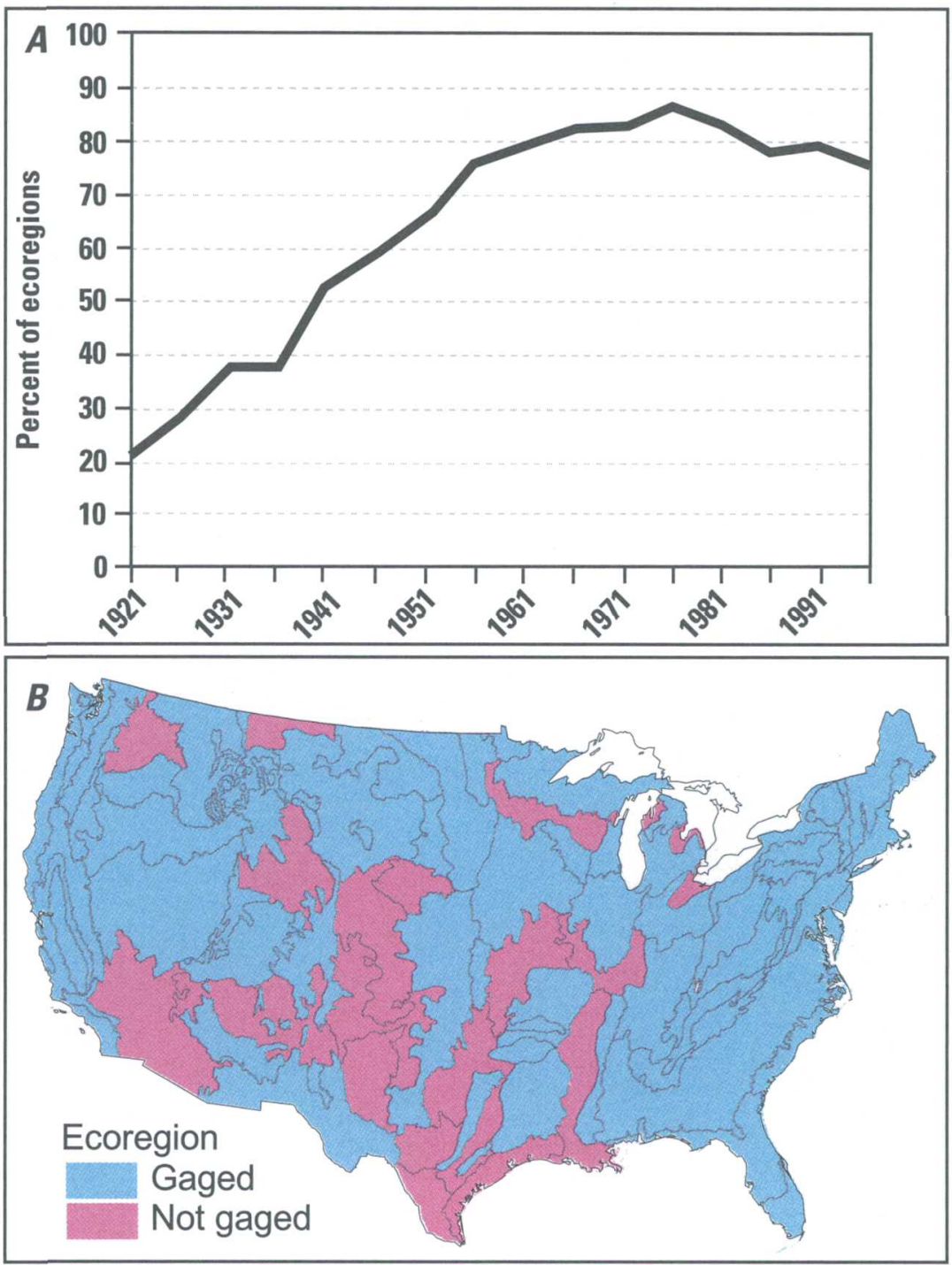

Figure 8.-Results of analysis for long-term changes. $\boldsymbol{A}$. Graph showing percentage of ecoregions that were adequately gaged, 1921-1996. B. Map showing, in cyan, ecoregions that were adequately gaged in 1996. Ecoregions not adequately gaged are shown in magenta. 


\section{Other Measures of the Loss of Information Needed to Evaluate Environmental Change}

The issue of streamgaging stations that can be used as indicators of long-term variation and change needs examination from some other perspectives beyond what can be seen from the long-term change metric above. One of these perspectives is simply to look at the changing population of long-term stations that are operated in any given year. In general, records of more than 30 years begin to be suitable for asking questions about trends in flow or in the variability of flows.

Figure 9 shows the number of long-record stations that have been discontinued in each year since 1921. Up through 1965, the number was generally no more than about 20 per year (typically about 1 percent of the total number of long-record stations). Since then, there have been three periods during which discontinuation of stations has accelerated. The losses in the middle 1990's show about 4 percent of the long-record streamgaging stations being discontinued each year. Much of the loss of long-term stations in recent years is attributable to the need for funding agencies to support current-use stations instead of long-term stations and the inability of the USGS to fund those stations with solely Federal appropriations

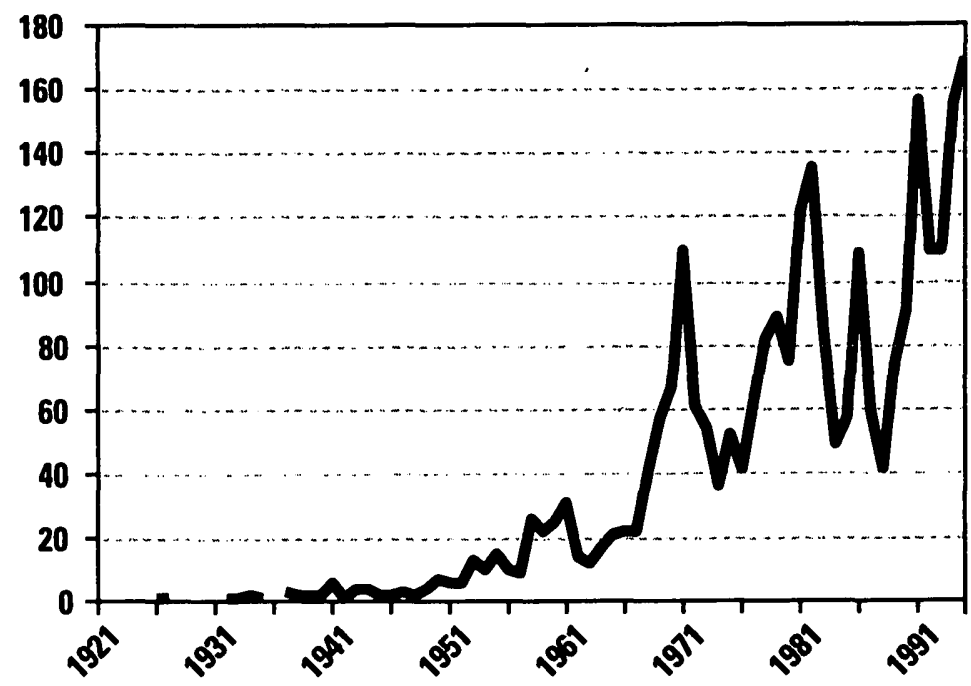

Figure 9.-Graph showing number of stations with 30 or more years of record discontinued each year, 1921-1995.

Still another way to look at the issue of information availability for long-term analysis is to consider a special subset of all USGS streamgaging stations: the Hydroclimatic Data Network (HCDN). This network was defined in 1988 and described in Slack and Landwehr (1993) and Slack and others (1993). The stations in this network have certain very specific qualities. They have all been gaged at least 20 years, and are subject to little or no flow regulation or diversion. They all represent sites, that if gaged for a sufficiently long period of time, provide data that are valuable for the study of the relationships between climate, landuse, and streamflow.

Figure 10 shows how the number of active HCDN stations in the network has changed over time. HCDN stations peaked in 1971 at 1,497 and has steadily declined since then to 1,161 , a decrease of 22 percent. These declines are disturbing in terms of the potential for understanding long-term changes taking place in the environment. 

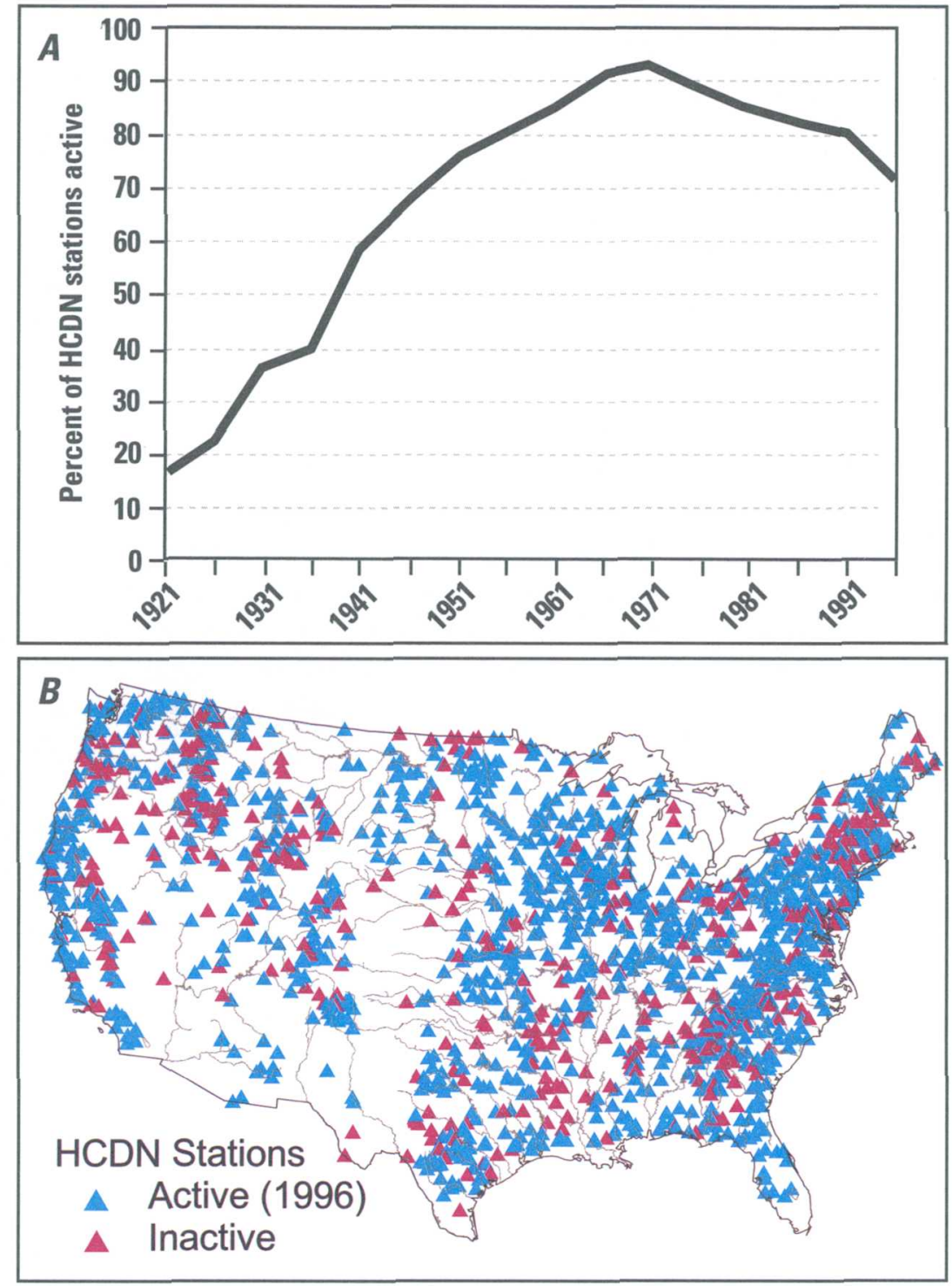

Figure 10.-A. Graph showing number of HCDN stations that were active, 19211996. B. Map showing, in cyan, HCDN stations active in 1996. HCDN stations inactive in 1996 are shown in magenta.

\section{Summary of Network Analysis}

Taking the Federal network goals together, we see a general pattern. In most cases the level of attainment of the metrics, as measures of the goals, typically rose steadily through the 1960 's or 1970's and then have either leveled off or declined. Some goals are now less well

\section{The level of attainment of Federal goals typically rose steadily through the 1960's or 1970's and then leveled off or declined.}

supported than in the 1950's and 1960's. This raises concerns for two reasons. The first is that the level of intensity of competition for the flow of the Nation's rivers and streams has continued to increase while the level of information about the resource is decreasing. The increased competition reflects the many new demands that our society and our system of laws and regulations are placing on the resources. 
A few decades ago the information needs focused on withdrawal uses, navigation, hydropower production, and flood risk estimation and flood mitigation projects. Today, it continues to involve all of these needs, but the needs have expanded to include water quality, aquatic and riparian habitat, and recreation. The second reason for concern is that streamgaging stations have now become significantly more useful through the use of modern technology. They not only fulfill their longterm future uses but also fulfill important current uses by providing realtime information needed to optimize water-resources operations and to provide flood warnings. So, we have increasing demands for information and yet the infrastructure to supply the information is declining.

\section{EVOLUTION OF FUNDING}

One of the major virtues of the streamgaging network is its shared

We have increasing demands for information and yet the infrastructure to supply the information is declining. funding arrangement. The USGS partners with more than 800 Federal, State, and local agencies through the Federal-State Cooperative Water Program (Water Coop Program). The Water Coop Program was formalized in appropriations law in 1929 and has been reaffirmed by the Congress every year since. Programmatically, the Water Coop Program provides the majority of funds for operating streamgaging stations-about two-thirds of the total (fig. 11). Other Federal agencies provide 28 percent and the USGS Federal Program provides the remaining 6 percent.

\section{Fiscal Year 1998 Funding Sources for USGS Streamgaging Network}

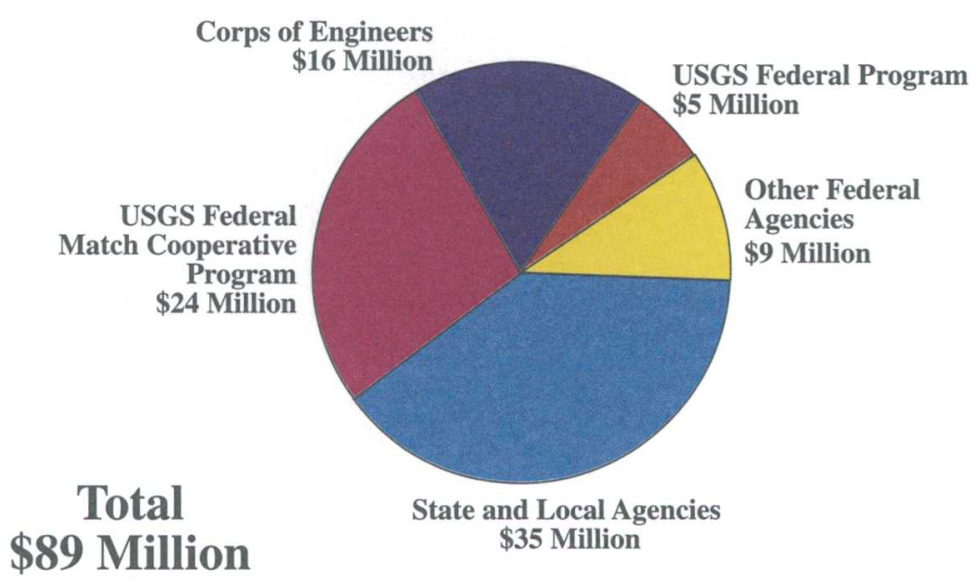

Figure 11.-Diagram showing the distribution of funding for the streamgaging network in 1998. 
Real resources

available to

operate the

streamgaging

network have

remained static

and the USGS

share of this

funding has

been declining in

recent years.
Over the longer term, the USGS Federal Program as a percentage of the total funds supporting stations also has declined (fig. 12). In 1974, the first year for which detailed funding data are available, the USGS Federal Program provided 11 percent of the total funds supporting the network. In 1998, this Program provided less than 6 percent, thereby reducing its relative influence by half. During this same period, the unmatched part of the Water Coop Program increased from less than 1 percent to its current level of 13 percent. Proportional funding from other Federal agencies increased slightly, from 25 percent to 28 percent, during this period.

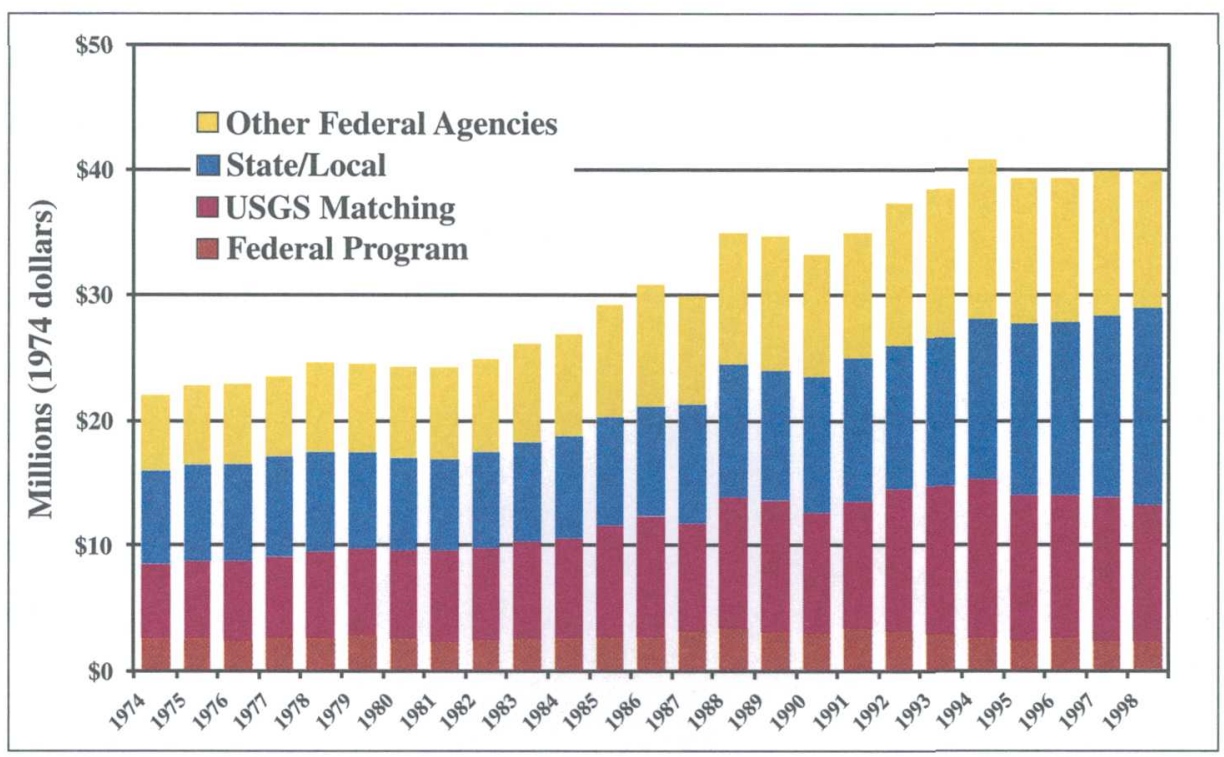

Figure 12.- Graph showing annual distribution of funding for the streamgaging network, 1974-1998. (Adjusted to 1974 using the GDP Product Index of Non-Defense Government Expenditures by Fiscal Year. Source: Bureau of Economic analysis, Department of Commerce.)

The real resources available to operate the streamgaging network (funds from all sources, adjusted for inflation) have been relatively static, particularly since 1992 . We also have been investing in new technology to replace outdated equipment and to meet the demand for real-time data. The net result is a decline in the total number of stations and a commensurate decline in the attainment for the Federal goals.

The declining relative share of USGS funding also has an impact. The USGS staff annually engages all potential funding agencies in discussions of possible network changes based on changing needs and changing availability of funds on all sides. The role of the USGS in these negotiations is to foster the Federal goals and apply the USGS funds towards the furtherance of these goals. The best outcome of these negotiations is a network configuration that satisfies the Federal goals and the goals of the funding partners. However, the smaller the share of the total funds that the USGS can bring to those negotiations, the poorer will be the bargaining position of the USGS to achieve the Federal goals. 


\section{The streamgaging network is part way through a transformation, from a system designed for long-term use to one designed for a combination of long- term and reliable real- time use.}

\section{Modernization Needs}

\section{- flood proofing \\ - extending streamflow ratings \\ - adding raingages \\ - backup systems \\ - technology review}

\section{MODERNIZATION}

In addition to the network evaluation described above, we have been examining and making investments in operational modernization of the stations and information delivery systems. These systems must be upgraded to accommodate new uses of the information and to take advantage of new technological capabilities.

The purposes of the streamgaging network have expanded significantly over its lifetime. The network infrastructure that exists today was largely funded and built to satisfy resource assessment, design and long-term planning goals. Capabilities to satisfy real-time data uses have been added in recent years, and yet additional investments are needed to allow the existing network to achieve the level of usefulness and reliability that is technically feasible today. These include floodproofing of stations, extending streamflow ratings, adding raingages to streamgaging stations, adding backup systems for data transmission, and research and development for enhanced streamgaging capabilities.

By their very nature, streamgaging stations are vulnerable to flood damages. They must be constructed near the river and shelters and instruments can be inundated, damaged or destroyed by flood-waters and flood-born debris. These risks can be minimized by incurring additional costs to make the structures taller (place critical electronic or mechanical components above potential high water), use stronger construction materials, or build the stations farther from the river channel and run longer connections to the river.

Extending streamflow ratings to levels higher than have been directly observed at stations will provide an invaluable service to the NWS and other organizations that need time-critical streamflow data during floods. Theoretical ratings based on laborintensive hydraulic surveys will provide real-time estimates of flood discharges for virtually any flood that could be anticipated at a streamgaging station.

Installing real-time rain gages at streamgaging stations with real-time telemetry is another cost-effective investment to support the Nation's flood forecasting capabilities. A major feature of the NWS modernization has been the deployment of 164 Doppler radar systems covering virtually the entire Nation. One weakness of the Doppler radar systems is that, although they do an excellent job of indicating the relative intensity of precipitation around a region, they are less successful at determining the actual quantity of rain. Additional real-time rainfall data would help them calibrate the radar data in each storm event, thus providing more accurate spatial distributions of rainfall to drive their floodforecast models. 
The longstanding programs of the USGS to collect and publish basic streamflow information provide very important information to a broad community of water users and water management organizations. .... The Commission received considerable comment about the need to maintain and ensure the continuity in this basic data collection program. Steps should be taken to develop among the agencies and cooperators a plan for this program that results in greater financial and programmatic stability, and this plan should be presented to the Congress for additional funding if needed. [Western Water Policy Review Advisory Commission, June 1998]

We believe the U.S.G.S. basic water quantity data collection activities are essential, because the value of hydrologic data increases with both the length and continuity of the record; the logical responsibility of the Federal Government, . . . . costeffective, because coordinated water data collection eliminates overlapping and duplicative efforts. These data are critical to a wide range of activities, . . .. How can engineers devise optimum responses, and design the most costeffective facilities, if they have incomplete and inadequate hydrologic data? [comments by William J. Carroll, President-Elect of the American Society of Civil Engineers, to the Subcommittee on Interior and Related Agencies, March 10, 1988]

The USGS streamgaging network is a unique and irreplaceable source of primary data supporting planning, research, and management for hydrologic hazards. [Water Science and Technology Board, National Research Council, 1998]
Delivering of current streamflow data to end users consists of many steps, each of which has some risk of failure. Achieving the full benefit of these current uses depends on having a high level of system reliability. One way to improve reliability is to provide backup systems for data transmission and dissemination to end users.

The streamgaging network is part way through a transformation, from a system designed for long-term use to one designed for a combination of long-term and reliable realtime use. For the past several years this transition has been funded by increasing the unit cost of individual stations. The steps described here are costly and attempts to fund them more rapidly out of current operating funds could cause additional increases in station costs and would result in withdrawal of some funding support from other agencies and discontinuation of stations. The USGS has proposed plans to modernize the streamgaging network for real-time data processing. We will use these plans and a vigorous program of research and development to identify new technologies for transforming the network in a manner that does not cause further harm to Federal network goals.

\section{FUTURE DIRECTIONS-NATIONAL STREAMFLOW INFORMATION PROGRAM}

The results of the streamgaging network evaluation indicate an obvious decline in the ability of the network to meet some Federal goals, especially those related to flooding and long-term environmental change. The USGS is now in a much better position to explain, in quantitative terms, how additional resources would enhance the national streamgaging network as well as describe in more detail the effects of reductions in these resources. We anticipate that this process will greatly improve the dialogue about how to enhance streamflow information for all the various stakeholders and ultimately result in a more useful and cost-effective network for the Nation. The network evaluation tool provides a basis for a planning effort now underway within the USGS. This planning effort is aimed at defining a "National Streamflow Information Program" (NSIP) that encompasses not only the stations themselves but the full suite of products that the program should produce, the delivery mechanisms for these products (e.g., World Wide Web), the needed modernization of the system, and a long-term research and development component for continually improving the program's effectiveness and efficiency. 
The network evaluation outlined in this report and the NSIP planning process will continue to involve the Streamgaging Task Force of the Advisory Committee on Water Information (ACWI). The ACWI is chartered under Office of Management and Budget Memorandum 92-01 following the procedures of the Federal Advisory Committee Act. Committee members include representatives of Federal, State, and local agencies, universities, the private sector, and nongovernmental organizations. We also will be sharing this report widely with interested parties in order to gain their reactions to the principles that we will be applying to the program's design.

The USGS planning team will integrate the feedback from the Streamgaging Task Force and other stakeholders as they design NSIP. We expect to have the key elements of the NSIP defined by March 1999. The development of NSIP plans aligns with the Department of the Interior's Government Performance and Results Act (GPRA) goal to "Provide science for a changing world." It further supports both GPRA goals of the USGS: 1) "Ensure the continued transfer of data, risk assessments, and disaster scenarios needed by our customers before, during, and after natural disasters;" and 2) "Ensure the continued availability of long-term environmental and natural resource information and systematic analysis and investigations needed by our customers." The metrics used in the network analysis are ideal for the ongoing tracking of these GPRA goals.

\section{CONCLUSIONS}

A few decades ago the information needs for streamgaging focused on withdrawal uses, navigation, hydropower production, flood risk estimation and mitigation projects, and flood forecasting. Those needs continue today, but they have expanded to include water quality, aquatic and riparian habitat, and recreation.

We have increasing demands for information and yet the infrastructure to supply the information is declining. For most Federal goals, the level of attainment of metrics typically rose steadily through the 1960's or 1970's, and then leveled off or declined since then. Some goals are now less well supported than in the 1960's. These declines are disturbing in terms of the ability to use long-term and current information to mitigate flood damages, and in terms of the potential for understanding long-term changes taking place in the environment.

Real resources available to operate the streamgaging network have remained static. The USGS relative share of this funding has been declining significantly and modernization needs remain unfulfilled. The smaller the share of the total funds that USGS can bring to negotiations, the poorer will be the bargaining position of the USGS to achieve Federal goals for the streamgaging network. The needs for information continue to grow but current funding levels and arrangements will not provide the means for the USGS to enhance or even maintain current levels of attainment of Federal mission goals. 


\section{REFERENCES}

Benson, M.A., and Carter, R.W., 1973, A national study of the streamflow data-collection program: U.S. Geological Survey Water-Supply Paper 2028, 44 p.

Cleaves, E.J., 1998, A call for a Federal streamgaging program: Geotimes, October 1998, 5p.

Fischer, E.E., 1996, Survey of users of the USGS stream-gaging network in Iowa, 1996: U.S. Geological Survey Open-File Report 96-185, 35 p.

Fontaine, R.A., Moss, M.E., Smath, J.A., and Thomas, W.O., 1984, Cost-effectiveness of the streamgaging program in Maine - a prototype for Nationwide implementation: U.S. Geological Survey Water-Supply Paper 2244, 39 p.

Jennings, M.E., Thomas, W.O., and Riggs, H.C., 1994, Nationwide Summary of U.S. Geological Survey regional regression equations for estimating magnitude and frequency of floods for ungaged sites, 1993: U.S. Geological Survey Water-Resources Investigations Report 94-4002, 196p.

National Weather Service, 1998, Flood Losses, Compilation of Flood Loss Statistics: National Oceanic and Atmospheric Administration, Hydrologic Infomration Center, accessed November 30, 1998, at url: http://www.nws.noaa.gov/oh/hic/flood_stats/Flood_loss_time_series.htm.

Omernik, J.M., 1987, Aquatic ecoregions of the conterminous United States. Annals of the Association of American Geographers, Volume 77, pp. 118-125.

Preston, S.D, 1997, Evaluation of the stream-gaging network in Maryland, Delaware, and Washington, D.C.: U.S. Geological Survey Fact Sheet FS--97-126, 4 p.

Seaber, P.R., Kapinos, F.P., Knapp, G.L., 1987, Hydrologic Unit Maps: U.S. Geological Survey WaterSupply Paper 2294, 63p., map.

Slack, J.R., and Landwehr, J.M., 1992, Hydro-Climatic Data Network (HCDN): A U.S. Geological Survey Streamflow Data Set for the United States for the Study of Climate Variations, 1874-1988: U.S. Geological Survey Open-File Report 92-129.

Slack, J.R., Lumb, A.M., Landwehr, J.M., 1993, Hydro-Climatic Data Network: (HCDN) Streamflow Data Set, 1874-1988: U.S. Geological Survey Water-Resources Investigations Report 93-4076. Compact Disk.

Team for Evaluating the Wisconsin Water-Monitoring Network, 1998, An integrated water-monitoring network for Wisconsin: Wisconsin Water Resources Center Special Report WRC SR 98-01, Water Resources Center, University of Wisconsin-Madison, $62 \mathrm{p}$.

Thomas, W.O., and Wahl, K.L., 1993, Summary of the nationwide analysis of the cost effectiveness of the U.S. Geological Survey stream-gaging program (1983-88): U.S. Geological Survey WaterResources Investigations Report 93-4168, 27 p.

U.S. Environmental Protection Agency (EPA), 1998, Introduction: Index of Watershed Indicators.

Wahl, K.L., Thomas, W.O., Jr., and Hirsch, R.M., 1995, Stream-gaging program of the U.S. Geological Survey: U.S. Geological Survey Circular 1123.

Water Science and Technology Board, 1998, Hydrologic Hazards Science at the U.S. Geological Survey: Committee on U.S. Geological Survey Water Resources Research, Water Science and Technology Board, Commission on Geosciences, Environment, and Resources, National Research Council, National Academy Press, Washington, D.C. 1998.

Western Governors' Association, 1997, An Action Plan for Reducing Flood Risk in the West: Western Governors' Association, Denver, Colorado, December, 1997, 12p. 